$12-1-2003$

\title{
Standards of Holistic Nursing Practice as Guidelines for Quality Undergraduate Nursing Curricula
}

Noreen Cavan Frisch

Cleveland State University, n.frisch@csuohio.edu

Follow this and additional works at: https://engagedscholarship.csuohio.edu/nurs_facpub

Part of the Nursing Commons

How does access to this work benefit you? Let us know!

Publisher's Statement

NOTICE: this is the author's version of a work that was accepted for publication in Journal of Professional Nursing. Changes resulting from the publishing process, such as peer review, editing, corrections, structural formatting, and other quality control mechanisms may not be reflected in this document. Changes may have been made to this work since it was submitted for publication. A definitive version was subsequently published in Journal of Professional Nursing, 19, 6, November - December 2003 DOI\#10.1016/S8755-7223(03)00128-5

\section{Recommended Citation}

Frisch, Noreen Cavan, "Standards of Holistic Nursing Practice as Guidelines for Quality Undergraduate Nursing Curricula" (2003). Nursing Faculty Publications. 42.

https://engagedscholarship.csuohio.edu/nurs_facpub/42

This Article is brought to you for free and open access by the School of Nursing at EngagedScholarship@CSU. It has been accepted for inclusion in Nursing Faculty Publications by an authorized administrator of EngagedScholarship@CSU. For more information, please contact library.es@csuohio.edu. 


\title{
Standards of Holistic Nursing Practice As Guidelines for Quality Undergraduate Nursing Curricula
}

\author{
Noreen Cavan Frisch, PhD, RN, FAAN
}

$\boldsymbol{S}_{\mathrm{N}}^{\mathrm{n}}$ INCE 1998, THE COMMISSION for Collegiate Nursing Education (CCNE) accreditation criteria have directed nursing faculty to select nationally developed standards for professional practice to guide curricula and to determine appropriate outcomes for both undergraduate and graduate programs. In 2003, the CCNE proposed a change in accreditation criteria to require the American Association of Colleges of Nursing (AACN) Essentials of Baccalaureate Education for Professional Nursing Practice (Essentials) (AACN, 1998) as a foundation for all CCNE-accredited undergraduate programs. The proposed criteria also state that additional standards and guidelines can be selected by faculty in keeping with their philosophies and the goals of their programs. Master's programs frequently identify appropriate standards as those developed for nursing specialties. However, undergraduate and prelicensure programs with the goal of preparing nursegeneralists might not as readily procure national standards for the entry level into professional practice. Because undergraduate programs seek to prepare the practitioner to provide care based on the theory and ethics of holism and have outcome criteria requiring the nurse to treat the client holistically, Standards of Holistic Nursing Practice (Standards), as developed by the American Holistic Nurses' Association (AHNA; Frisch, Dossey, Guzzetta, \& Quinn, 2000), is an appropriate set of standards to guide both curricula and professional practice. The purposes of this paper are to describe Standards, to present guidelines for how these standards can be incorporated into the undergraduate curriculum, and to provide a comparison of emphases between Essentials and Standards.

\section{AHNA Standards of Holistic Nursing Practice DEVELOPMENT}

Standards was developed by the AHNA as a set of guidelines to serve as a foundation for the practice of holistic nursing (Frisch et al., 2000). Standards is written at the level of baccalaureate competencies that require the practitioner to embrace a philosophy of holism and to possess the knowledge and skills to provide reflective care that is compassionate and evidencebased in collaboration with clients' desires and needs. Standards is based on the core values that underpin all professional nursing work: (1) philosophy and education; (2) ethics, theories, and research; (3) holistic nurse self-care; (4) communication, therapeutic environment, and cultural diversity; and (5) the holistic caring process. Standards does not advocate changing aspects of care being provided by professional nurses 
adhering to nursing theory and current evidence about care; however, it substantially raises awareness and changes the emphasis of one's practice to that of dealing with client and self from a holistic perspective.

Standards was developed and revised during the decade 1990-2000 (Dossey, 2000). Initially, the AHNA set out to conceptualize the professional practice that met the modern challenges of incorporating technology, mind, and spirit into nursing care. The organization's goal is simply stated: "to unite nurses in healing" (http//www.ahna.org/about/about.htm), and its mission is to "focus on holistic principles of health, preventive education, and the integration of allopathic and complementary caring-healing modalities to facilitate care for the whole client and significant others" (Dossey, 2000, p. xv). Initially, Standards was developed by a committee of people nationally known for their work in nursing theory and holism. It was divided into two sections: Part 1, which dealt with the discipline of holistic nursing practice and included philosophy, ethics, theory, research, and application of the nursing process; and Part 2 , which dealt with the caring and healing of the client and significant others and included the concepts of meaning and wholeness, client self-care, and health promotion. Standards served as a statement of practice for holistic nursing and was disseminated through the AHNA.

With the advent of a certification process for holistic nursing, the initial Standards was reviewed and updated, again by a task force of people known for work in this area. This second review process included a literature review, a national role-delineation study, and feedback from a nationally selected advisory committee and practice review committee (Dossey, 2000). The literature review consisted of a review of all articles published over a 10-year period in the Journal of Holistic Nursing, Holistic Nursing Practice, and other journal and book publications addressing holism and holistic nursing. The task force assumed that a 10-year publishing history would provide information delineating the domain, scope, and boundaries of holistic nursing (Dossey, 2000). Next, the task force undertook a role-delineation study of the practice of AHNA members who identified their practice as reflecting holistic nursing care. This study was a survey of the knowledge, attitudes, and skills required for holistic nursing practice. The survey tool was developed through the literature review cited above, a review of 37 holistic/complementary educational or clinical programs, and interviews with selected programs (Dossey, Frisch, Forker, \& Lavin, 1998). The survey tool was reviewed and modified by feedback from an advisory committee with the guidance of staff from the $\mathrm{Na}$ - tional League for Nursing (NLN) Assessment and Evaluation office. The survey was administered in 1996 and resulted in data from 708 nurses describing the day-to-day attitudes, knowledge, and skills required for holistic nursing practice (Dossey et al., 1998). These data provided content validity to the certification process and also provided insights into practice definitions and foci of holistic nursing care. Subsequently, these data were reviewed by the AHNA Standards Task Force, along with the existing Standards, and evaluated by a 24-member Practice Review Committee and a 10-member AHNA Leadership Committee through a Delphi panel technique to achieve consensus on revisions. Today, Standards represents a consensus based on review by six members of the AHNA Task Force and the 34 members of the Advisory and Leadership Committee (Dossey, 2000). Thus, Standards is national in scope and has been developed by a consensus of nursing professionals with a vested interest in bringing holism into nursing practice.

\section{DESCRIPTION}

Currently, Standards is divided into Core Values, with each Core Value having a definition or description and a series of practice standards specifically addressing the behaviors, attitudes, and dispositions required to meet the intent of that value. Table 1 presents the Core Values. Table 2 presents the specific practice standards for Core Value 1.1 to illustrate the level of description in each Core Value statement. Standards provides specific guidelines for demonstrating that the standards are being carried out and is available from the AHNA (Frisch et al., 2000).

\section{Use of the Standards in Undergraduate Nursing Curricula}

Standards can be used to guide curriculum, teaching activities, and practice outcomes for any undergraduate program that has holism as its goal and that functions under a philosophy that embraces holistic care. Each concept addressed in the Core Values could become a curricular thread or pervasive concept developed over the course of the curriculum. Conversely, concepts foundational to nursing could be taught at the beginning of the program, and additional concepts could be added where appropriate, based on where content appears in the program. The first option is an "all-at-once" approach whereby the standards described could be introduced in beginning courses and 
Core Value 1: Holistic Philosophy and Education

Holistic Philosophy: Holistic nurses develop and expand their conceptual framework and overall philosophy in the art and science of holistic nursing to model, practice, teach, and conduct research in the most effective manner possible

Holistic Education: Holistic nurses acquire and maintain current knowledge and competency in holistic nursing practice

Core Value 2: Holistic Ethics, Theories, and Research

Holistic Ethics: Holistic nurses hold to a professional ethic of caring and healing that seeks to preserve wholeness and dignity of self, students, colleagues, and the person who is receiving care in all practice settings, be it in health promotion, birthing centers, acute or chronic health care facilities, end-of-life care centers, or in homes

Holistic Nursing Theories: Holistic nurses recognize that holistic nursing theories provide the framework for all aspects of holistic nursing practice and transformational leadership

Holistic Nursing and Related Research: Holistic nurses provide care and guidance to persons through nursing interventions and holistic therapies consistent with research findings and other sound evidence

Core Value 3: Holistic Nurse Self-Care

Holistic Nurse Self-Care: Holistic nurses engage in self-care and further develop their own personal awareness of being an instrument of healing to better serve self and others

Core Value 4: Holistic Communication, Therapeutic Environment, and Cultural Diversity

Holistic Communication: Holistic nurses engage in communication to ensure that each person experiences the presence of the nurse as authentic and sincere; there is an atmosphere of shared humanness that includes a sense of connectedness and attention reflecting the individual's uniqueness

Therapeutic Environment: Holistic nurses recognize that each person's environment includes everything that surrounds the individual, both the external and the internal (physical, mental, emotional, social, and spiritual) as well as patterns not yet understood.

Cultural Diversity: Holistic nurses recognize each person as a whole body-mind-spirit and mutually create a plan of care consistent with cultural background, health beliefs, sexual orientation, values, and preferences

Core Value 5: Holistic Caring Process

Assessment: Each client is assessed holistically using appropriate traditional and holistic methods while the uniqueness of the client is honored Patterns/Problems/Needs: Actual and potential patterns/problems/needs and life processes related to health, wellness, disease, or illness, which may or may not facilitate well-being, are identified and prioritized

Outcomes: Each client's actual or potential patterns/problems/needs have appropriate outcomes specified

Therapeutic Care Plan: Each client engages with the holistic nurse to mutually create an appropriate plan of care that focuses on health promotion, recovery or restoration, or peaceful dying so that the person is as independent as possible

Implementation: Each client's plan of care is prioritized, and holistic nursing interventions are implemented accordingly

Evaluation: Each client's responses to holistic care are regularly and systematically evaluated, and the continuing holistic nature of the health process is recognized and honored

Source: Standards of Holistic Nursing Practice (2000). Flagstaff, AZ: AHNA. Reprinted with permission.

reassessed and developed according to the knowledge and skills added at each level of coursework. The second option would take concepts assumed to be foundational to success in holistic nursing (philosophy of holism, ethics, theory, cultural diversity, and self-care) as essential concepts for initial nursing classes. Concepts requiring development over the course of a program-research, communication, therapeutic environment, and the holistic caring process-would be introduced and tracked across courses so that the stu- dent could build expertise in these areas as she or he progresses through the curricula. Table 3 gives an example of the use of major concepts in holistic nursing across three levels of a nursing program.

\section{Comparison Between Holistic Standards and AACN Essentials}

There are several areas of congruence between Standards and Essentials. In each, there is clear attention to

\section{TABLE 2. Core Value 1.1 with Standards of Practice}

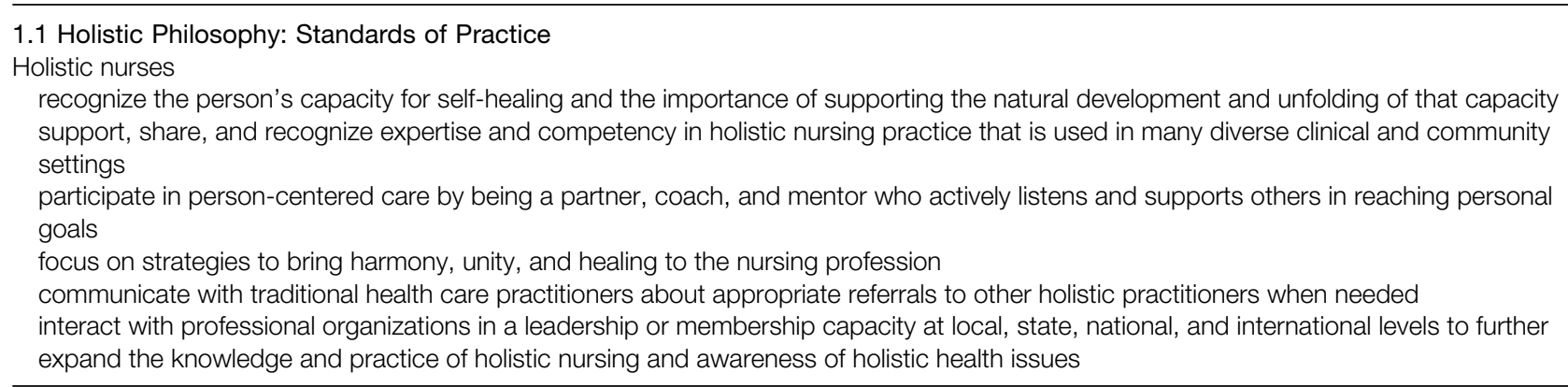

Source: Standards of Holistic Nursing Practice (2000). Flagstaff, AZ: AHNA. Reprinted with permission. 
TABLE 3. Concepts in AHNA Standards Across Three Levels of Nursing Courses

\begin{tabular}{|c|c|c|c|}
\hline Concept & Sophomore Level & Junior Level & Senior Level \\
\hline $\begin{array}{l}\text { Holistic } \\
\text { philosophy }\end{array}$ & $\begin{array}{l}\text { writes personal philosophy based on knowledge } \\
\text { of holism }\end{array}$ & applies philosophy & $\begin{array}{l}\text { reflects and revises } \\
\text { personal philosophy } \\
\text { for practice }\end{array}$ \\
\hline Ethics & understands ethical theory & applies ethical principles in practice & $\begin{array}{l}\text { internalizes ethical } \\
\text { principles for } \\
\text { beginning } \\
\text { professional practice }\end{array}$ \\
\hline Theory & understands theoretical perspectives & $\begin{array}{l}\text { applies theory to practice; compares/ } \\
\text { contrasts theories }\end{array}$ & $\begin{array}{l}\text { synthesizes theory in } \\
\text { practice settings }\end{array}$ \\
\hline $\begin{array}{l}\text { Cultural/Human } \\
\text { diversity }\end{array}$ & $\begin{array}{l}\text { describes similarities and differences among } \\
\text { people }\end{array}$ & \multicolumn{2}{|c|}{$\begin{array}{l}\text { uses knowledge of in practice decisions of increasing } \\
\text { complexity }\end{array}$} \\
\hline Research & $\begin{array}{l}\text { acknowledges the need for evidence in practice } \\
\text { decisions }\end{array}$ & reads and critiques research articles & $\begin{array}{l}\text { uses published } \\
\text { research findings as } \\
\text { evidence for practice } \\
\text { decisions }\end{array}$ \\
\hline Self-care & \multicolumn{3}{|c|}{ learns self-care techniques and practices/applies techniques throughout educational program } \\
\hline Communication & demonstrates professional communication & $\begin{array}{l}\text { demonstrates therapeutic } \\
\text { communication }\end{array}$ & $\begin{array}{l}\text { extends } \\
\text { communication skills } \\
\text { to community/group } \\
\text { settings }\end{array}$ \\
\hline $\begin{array}{l}\text { Therapeutic } \\
\text { environment }\end{array}$ & $\begin{array}{l}\text { maintains an environment conducive to healing } \\
\text { (structured settings) }\end{array}$ & \multicolumn{2}{|c|}{$\begin{array}{l}\text { maintains an environment conducive to healing in increasingly } \\
\text { unpredictable and unstructured settings }\end{array}$} \\
\hline $\begin{array}{l}\text { Holistic caring } \\
\text { process }\end{array}$ & initiates nursing practice based on the process & \multicolumn{2}{|c|}{$\begin{array}{l}\text { moves practice to increasing levels of complexity and diversity } \\
\text { in keeping with standards of holism }\end{array}$} \\
\hline
\end{tabular}

(1) the demonstration of professional ethics and values;

(2) the need for professional and therapeutic communication; (3) the acknowledgment of human and cultural diversity; (4) quality care based on assessment, sound judgment, and current research; (5) the nursing roles of care provider, manager, and member of a profession; and (6) education as a lifelong endeavor.

Differences between the two documents lie in the emphasis in Essentials on liberal education as a foundation to nursing education and the need for professional nurses to understand health systems and policies. These concepts are not specifically addressed in Standards, although they could be inferred as a prerequisite to the development of one's personal philosophy of care (liberal education) and as needed in the role of health care advocate (health systems/policy). Con- versely, Standards specifically addresses a mandate for personal self-care and for professional practice based on personal philosophy and articulated through theory. Table 4 illustrates the overlapping concepts and the differing emphases between the two documents. Also, because Standards is written to guide practice, it includes not only the major concepts but also the behaviors, knowledge, and skills required to demonstrate the achievement of each standard. For example, to achieve the practice competencies associated with cultural congruence, the first standard of practice states that the nurse "assesses and incorporates the person's cultural practices, values, beliefs, meaning of health, illness, and risk behaviors in care and health education"(Quinn, 2000, p. 109) and that demonstrable skills include the ability to use cultural

TABLE 4. Emphasis in AHNA Standards and AACN Essentials: Similarities and Differences

\begin{tabular}{cl}
\hline $\begin{array}{c}\text { Concepts found in Both AHNA Standards and } \\
\text { AACN Essentials }\end{array}$ & Concepts Accentuated in Standards \\
\hline $\begin{array}{l}\text { Professional values, Altruism, Autonomy, } \\
\text { Human dignity, Integrity, Social justice, }\end{array}$ & $\begin{array}{l}\text { Nurse self-care, Theory as } \\
\text { foundational to practice, Therapeutic } \\
\text { environment, Care of the } \\
\text { Ethics, Research, Human diversity/Cultural }\end{array}$ \\
$\begin{array}{l}\text { congruence, Professional roles, Designer/ } \\
\text { Manager of care, Member of a profession, }\end{array}$ \\
Lifelong learning
\end{tabular}


client assessment techniques and cultural competence with interventions and intercultural communications (p. 109). This level of detail in describing practice expectations could provide faculty with items useful in articulating the level and terminal curricular objectives of their programs.

\section{Discussion}

The two documents, the AACN Essentials and the AHNA Standards, are complementary and can be used together to define the knowledge, skills, and outcomes of an undergraduate or prelicensure nursing program. Use of both documents could benefit programs by helping to clarify the essential concepts and outcomes of education. Standards emphasizes that professional holistic care is guided by theory and is based on an articulated personal philosophy. Some might suggest that it is precisely this emphasis on personal philosophy and theory-based practice that distinguishes professional nursing care from technical care. The ideas of stated theory and philosophy are consistent with the emphasis in Essentials on liberal education and critical thinking as a required component of professional curricula. In addition, Standards emphasizes that, because the nurse uses "self" as an instrument of healing, personal self-care is required to serve self and others. Faculty who consider self-care as part of the practice of nursing could easily bring the self-care standard into the curriculum and give students the tools for developing adequate self-care practices throughout the nursing program.

Many who have identified themselves as holistic nurses believe that nursing is, by definition, holistic (Frisch, 1999). As faculty seek to organize curricula in logical and coherent ways, an organizing framework that uses one of many holistically oriented nursing theories and patterns its terminal and level objectives after the Standards will meet the expected outcomes for undergraduate programs. Data from a national study (McEwen \& Brown, 2002) of the conceptual frameworks used in undergraduate curricula indicated that 33 percent of nursing programs use a nurse theorist as a basis for a conceptual framework and that baccalaureate programs tend to incorporate all four components of the nursing metaparadigm into the curricula. It is reasonable to conclude that many programs could readily benefit from review and incorporation of the holistic Standards when undergoing a self-study review. Discussing the accreditation process, Van Ort and Townsend (2000) comment that "Accreditation by CCNE offers a process of assessing the quality of nursing programs while encouraging flexibility and innovation" (p. 330). Blending the concepts of Essentials and the Standards documents provides an innovative approach to the application of national standards in curriculum design when the outcome is a professional nurse committed to the concept of holism in nursing.

\section{References}

American Association of Colleges of Nursing (1998). The essentials of baccalaureate education for professional nursing practice). Washington, DC: Author.

Commission on Collegiate Nursing Education. (2003). Proposed standards for accreditation of baccalaureate and graduate nursing programs. Retrieved May 31, 2003, from http:// www.aacn, nche.edu/Accreditation/standards.htm.

Dossey, B. (2000). Introduction. In N. Frisch, B. Dossey, C. Guzzetta, \& J. Quinn, AHNA standards of holistic nursing practice with guidelines for caring and healing (pp. $\mathrm{xv}-\mathrm{xlii}$ ). Gaithersberg, MD: Aspen.

Dossey, B., Frisch, N., Forker, J., \& Lavin, J. (1998). Evolving a blueprint for certification: Inventory of professional activities and knowledge of a holistic nurse (IPAKHN). Journal of Holistic Nursing, 16(1), 33-55.

Frisch, N. (1999). Nursing Theory. In B. Dossey, L. Keegan, \& C. Guzzetta (Eds.), Holistic nursing, a hand- book for practice (3rd ed., pp. 173-192). Gaithersberg, MD: Aspen.

Frisch, N., Dossey, B., Guzzetta, C, \& Quinn, J. (2000). AHNA standards of holistic nursing practice with guidelines for caring and healing). Gaithersberg, MD: Aspen.

McEwen, M., \& Brown, S. (2002). Conceptual frameworks in undergraduate nursingcurricula: Report of a national survey. Journal of Nursing Education, 41(1), 5-14.

Quinn, J. (2000). Core Value 4: Holistic communication, therapeutic environment, and cultural diversity. In $\mathrm{N}$. Frisch, B. Dossey, C. Guzzetta, \& J. Quinn, AHNA standards of holistic nursing practice with guidelines for caring and healing (pp. 75-118). Gaithersberg, MD: Aspen.

Van Ort, S., \& Townsend, J. (2000). Community-based nursing education and nursing accreditation by the Commission on Collegiate Nursing Education. Journal of Professional Nursing, 15, 330-335. 